S. Fekete

I. Hullár

Emese Andrásofszky

A. Bersényi

I. Szakáll

\title{
Changes in body composition of growing rabbits owing to age and sex
}

\section{Körperzusammensetzung beim wachsenden Kaninchen}

Offspring of 24, artificially inseminated New Zealand White does were involved in the 12-week-long trial. The lactating does were fed exclusively with a commercial pelleted concentrate ad libitum. The same pellets are the single creep feed for the suckling rabbits besides the mother's milk and also later from weaning until the end of the experiment (day 84). The does were induced to kindle at the same time by receiving 4 IU oxytocin injection intramuscular on day 31 of their pregnancy.

On day $0,7,14,21,28,35,42,49,56,63,70,77$, and 84 the rabbits were individually weighed and 3 male and 3 female individuals have been chosen for the body composition analysis. Until the weaning (day 42) the sampling was unproportional in the litters in order to maintain the average in litter size of eight for the remaining does. The selected rabbits were tranquillized by pentobarbital injection and stored at $-20^{\circ} \mathrm{C}$.

Before the chemical analysis the gut content was removed and the empty bodies individually ground. The 39 male and 39 female growing rabbits' body composition were determined by direct chemical analysis according to the A.O.A.C. (1975) recommendation.

One can state that the dry matter content continuously increased from birth to day 14 . After that the changes are practically negligible until the day 63 then followed by a slight increase. The ash content increased until day 35 , after that practically remained unchanged until day 56. At the end of the experimental period its proportion tended to be lower. The crude protein concentration continuously increased from birth to the end of the experimental period (day 84) although the curve is flatter.

The fat (ether extract) content reached its maximum on day 14 , followed by a decline until day 56 , attaining the initial (day 0) concentration. After that its proportion was higher continuously.

Until day 14 the augmentation of crude protein, fat, and mineral (ash) retention could occur on account of the water content. Given the fact that from day 14 to 63 the dry matter progressive decrease of content practically did not vary, but the content of fat decreased, the increasing protein and mineral production must have been realized at the cost of the fat. After the 9 th week of age the slight increase of the body protein and fat content could have been a result of the decreased water content.

According to the present data the 6-week-old growing rabbit had not yet reached the state of chemical maturity. During the first 12 weeks, no sex differences was detected in the dry matter, ash, crude protein and fat concentrations of the empty body. However, the fat content of females increased faster from day 77 . 